\title{
In vitro probiotic potential of Lactobacillus spp. isolated from fermented milks
}

\author{
[Potencial probiótico in vitro de Lactobacillus spp. isolados de leites fermentados] \\ A.F. Cunha, L.B. Acurcio, B.S. Assis, D.L.S. Oliveira, M.O. Leite, \\ M.M.O.P. Cerqueira, M.R. Souza \\ Escola de Veterinária - Universidade Federal de Minas Gerais- Belo Horizonte, MG
}

\begin{abstract}
The potential of in vitro probiotic Lactobacillus spp. was evaluated in fermented milks marketed in Belo Horizonte, MG, Brazil. Of the samples analyzed, $86.7 \%$ had at least $10^{6} \mathrm{CFU} / \mathrm{mL}$ of Lactobacillus spp., complying with the Brazilian quality standards for fermented milks. Furthermore, $56.7 \%$ had minimum count ranging from $10^{8}$ to $10^{9} \mathrm{CFU} / \mathrm{mL}$, which is in accordance with legal parameters. The remaining $43.3 \%$ would not be able to satisfactorily guarantee benefits to consumers. The amount of Lactobacillus spp. varied between batches of products, which may indicate failures in monitoring during manufacture, transport or storage. All strains of Lactobacillus spp. showed some inhibitory activity against the indicator microorganisms, being more pronounced against pathogenic microorganisms than against non-pathogenic $(\mathrm{P}<0.05)$. Samples of Lactobacillus spp. showed different profiles of antimicrobial susceptibility, with an occurrence of cases of multidrug resistance. All strains tested showed sensitivity to bile salts $(0.3 \%)$ and resistance to gastric $\mathrm{pH}(2.0)$. Lactobacillus spp. of commercial fermented milks should be present in higher amounts in some brands, be resistant to bile salts and have no multiple resistance to antimicrobials.
\end{abstract}

Keywords: Lactobacillus spp., fermented milks, probiotic

\section{RESUMO}

O potencial probiótico in vitro de Lactobacillus spp. foi avaliado em leites fermentados comercializados em Belo Horizonte, MG, Brasil. Das amostras analisadas, 86,7\% apresentaram quantidade mínima de $10^{6} \mathrm{UFC} / \mathrm{mL}$ de Lactobacillus spp., enquadrando-se no padrão brasileiro de qualidade de leites fermentados. Além disso, 56,7\% apresentaram quantidade mínima de $10^{8}$ a $10^{9} \mathrm{UFC} / \mathrm{mL}$, estando em conformidade com os parâmetros legais vigentes. As demais 43,3\% não estariam aptas a garantir satisfatoriamente efeitos benéficos aos consumidores. Observou-se variação na quantidade de Lactobacillus spp. entre lotes dos produtos, o que pode indicar falhas no monitoramento durante a fabricação, transporte ou estocagem destes. Todas as amostras de Lactobacillus spp. demonstraram alguma atividade inibitória frente aos microrganismos indicadores, sendo mais intensa contra microrganismos patogênicos que não patogênicos $(P<0,05)$. As amostras de Lactobacillus spp. apresentaram diferentes perfis de susceptibilidade aos antimicrobianos, ocorrendo casos de multirresistência. Todas as amostras testadas apresentaram sensibilidade in vitro a sais biliares $(0,3 \%)$ e resistência in vitro ao pH gástrico (2,0). Lactobacillus spp. dos leites fermentados testados deveriam estar presentes em quantidades mais elevadas em algumas marcas comerciais, possuir resistência aos sais biliares e não apresentar resistência múltipla aos antimicrobianos.

Palavras chave: Lactobacillus spp., leite fermentado, probiótico

\section{INTRODUCTION}

Fermented milks are products resulting from fermentation of pasteurized or sterilized milk by specific cultures of microorganisms, which must be viable, active and abundant in the final product throughout its shelf life (Brasil, 2007). The major lactic acid bacteria used to produce fermented milk products belong to the genera Lactobacillus, Lactococcus, Leuconostoc and Streptococcus. In most cases, they are made with lactic cultures of bacteria of the genus Lactobacillus and are responsible for sensory

Recebido em 29 de setembro de 2012

Aceito em 30 de julho de 2013

E-mail: adrianofcunha@yahoo.com.br 
characteristics in the product through the production of acids and carbonyl compounds. These acids also reduce the $\mathrm{pH}$, inhibit the growth of spoilage and pathogenic microorganisms (Robinson, 1991).

Probiotics are live microorganisms that when ingested in adequate amounts, exert health benefits to the consumer, other than those related to nutritional effects (Joint FAO/WHO/OIE, 2003). The effects designated include: relief of symptoms of lactose intolerance, modulation immune system and intestinal microbiota (treatment and prevention of diarrhea), hypocholesterolemic and anticarcinogenic action (Gupta and Garg, 2009; Reid, 2012).

The beneficial effect of probiotic bacteria to the host is related to its concentration in the lumen of the intestine, whose value must be at least $1 \times 10^{7} \mathrm{CFU} / \mathrm{g}$ of fecal content. According to the National Agency of Sanitary Surveillance of the Ministry of Health (Brasil, 2008), a probiotic product presents a claim for health promotion, if the minimum viable culture is between $10^{8}$ and $10^{9} \mathrm{CFU}$ per gram of product. However, the Normative Instruction 46 of the Ministry of Agriculture, Livestock and Food Supply (Brasil, 2007), establishes a minimum threshold of $1 \times 10^{6} \mathrm{CFU}$ per gram of product as a requirement of lactic acid bacteria from fermented milk quality.

Considering the technological perspective of using these lactic acid bacteria for food preservation and control of pathogens, the objective of this study was to investigate the potential of probiotic microorganisms in fermented milk products in Belo Horizonte (MG).

\section{MATERIAL AND METHODS}

Milk fermented by Lactobacillus spp. were obtained from the retail market of Belo Horizonte (MG) and sent refrigerated to the Laboratory of Food Microbiology, Department of Technology and Inspection of Animal Products, School of Veterinary Medicine, Federal University of Minas Gerais, Brazil. Thirty samples from six different brands (A, B, C, D, E and F) with five different batches of each brand were analyzed.
The samples were diluted $\left(10^{-5}, 10^{-6}\right.$ and $\left.10^{-7}\right)$ in saline $0.85 \%$ peptone (w/v) and subsequently an aliquot of $100 \mathrm{~mL}$ of each dilution in triplicate was poured Petri dishes on agar MRS (Difco, Detroit, USA). The plates were incubated for $48 \mathrm{~h}$ at $37^{\circ} \mathrm{C}$ under aerobic conditions. After this incubation period, the count of Lactobacillus spp. considered plates that had 40-250 colonies. After isolation, Gram staining was performed (Vanderzant and Splittstoesser, 1992).

Lactobacillus spp. isolated in MRS agar (Difco) were incubated in MRS broth (Difco) at $37^{\circ} \mathrm{C}$ for $24 \mathrm{~h}$ under aerobic conditions. Then the microorganisms were preserved at $-20^{\circ} \mathrm{C}$ in Eppendorfs containing glycerin. The in vitro antagonism test (Tagg et al., 1976) was performed in triplicate for each sample batch assessed except for batch brand F. Microorganisms this brand showed no growth, when the test was conducted.

After two activations, $5 \mu \mathrm{L}$ of Lactobacillus spp. culture were inoculated in the center of the Petri dishes containing agar MRS (Difco) and incubated for $48 \mathrm{~h}$. Then, chloroform was added in the lids of the plates and allowed to act for $30 \mathrm{~min}$ to remove the microorganisms grown. The antagonist activity was tested against bacteria including Lactobacillus casei and revealing $L$. acidophilus, isolated from these fermented milks and also commercial $L$. acidophilus ICB, Salmonella enterica serovar Typhimurium ATCC 13076, Staphylococcus aureus ATCC 29313 and Escherichia coli ATCC 25922, kindly given by Professor Jacques Robert Nicoli, ICB, UFMG. All indicator bacteria were activated twice at $37^{\circ} \mathrm{C}$ for $24 \mathrm{~h}$ under aerobic conditions. Then $10 \mu \mathrm{L}$ of culture was transferred to $3.5 \mathrm{~mL}$ of semi-solid agar BHI (Oxoid, Basingstoke, England) or MRS (Difco). After stirring, it was poured on MRS agar plates (Difco), after inactivation of the samples of Lactobacillus spp. The plates were incubated at $37^{\circ} \mathrm{C}$ for $24 \mathrm{~h}$ under aerobic conditions. The measure (in $\mathrm{mm}$ ) of inhibition zones was performed using a digital caliper Mitutoyo Digimatic Caliper (Mitutoyo Sul Americana Ltda, São Paulo, Brasil).

The evaluation of in vitro susceptibility to antimicrobial agents was performed in triplicate, according to technique adapted antimicrobial susceptibility disks (Charteris et al., 1998). After 
two activations $\left(37^{\circ} \mathrm{C}, 24 \mathrm{~h}\right.$ under aerobic conditions), the microorganisms were grown in MRS agar (Difco) for 24 to $48 \mathrm{~h}$ at $37^{\circ} \mathrm{C}$. Then, portions of the colonies were transferred to tubes containing $3.5 \mathrm{~mL}$ of saline $0.85 \%$ peptone $(\mathrm{w} / \mathrm{v})$ to give the corresponding to 1.0 at McFarland standard. The dilutions were subjected to bacterial count according to the methodology described by Vanderzant and Splittstoesser (1992). Then, inoculum was made using swabs on the surface of plates $(14 \mathrm{~cm}$ diameter $)$ containing MRS agar (Difco).

Soon after, disks were distributed (Oxoid) containing the following antimicrobial agents, with their respective concentrations: gentamicin (10mg), erythromycin (15ug), clindamycin $(2 \mu \mathrm{g})$, ciprofloxacin $(5 \mu \mathrm{g})$, ceftazidime $(30 \mu \mathrm{g})$, streptomycin (10mg), penicillin (10 IU), oxacillin $(1 \mu \mathrm{g})$, vancomycin $(30 \mu \mathrm{g})$, and tetracycline $(30 \mu \mathrm{g})$. After incubation, with the aid of a digital caliper, the diameters of inhibition zones were measured using a digital pachymeter Mitutoyo Digimatic Caliper (Mitutoyo Ltd.). Quality control of the discs was performed using $E$. coli ATCC 25922. The profile of susceptibility to the antimicrobial Lactobacillus spp. isolated from fermented milk was determined according to the methodology described by Charteris et al. (1998).

Sensitivity tests to the gastric $\mathrm{pH}$ and bile salts were performed in duplicate, adapting the technique of Walker and Gilliland (1993). Samples of microorganisms isolated from fermented milk were twice grown in MRS broth (Difco) at $37^{\circ} \mathrm{C}$ for $24 \mathrm{~h}$ under aerobic conditions. The inoculum size of each sample was added to $1 \mathrm{~mL}$ of a $0.85 \%$ saline $\mathrm{pH} 2.0$ and $\mathrm{pH} 7.0$ and incubated at $37^{\circ} \mathrm{C}$ for $3 \mathrm{~h}$. Pellets were then obtained through centrifugation at $18.327 \mathrm{x} \mathrm{g}$ at room temperature for $1 \mathrm{~min}$. and suspended in MRS broth (Difco). Then, $10 \mu \mathrm{L}$ were the transferred to $200 \mu \mathrm{L}$ in an individual well of a 96-well ELISA plate: three from $\mathrm{pH} 2.0$ (gastric $\mathrm{pH}$ ) incubation and three from saline $\mathrm{pH} 7.0$ (control) incubation. Then, the Optical Density (OD) readings were carried out at $620 \mathrm{~nm}$, with an interval of $30 \mathrm{~min}$ for $12 \mathrm{~h}$ of incubation at $37^{\circ} \mathrm{C}$ in the spectrophotometer Microplate Spectrophometer model Spectramax 340 (Molecular Devices). The percentage of growth inhibition was calculated as the difference between the areas of the growth rate using the software Origin 8.5 (OriginLab, Massachusetts, USA), adapted to Mota et al. (2006). To test for sensitivity to bile salts, the samples were placed in a 96-well ELISA microplate, in triplicate, in the presence of MRS broth (Difco) (control) and MRS broth (Difco) $0.3 \%$ Oxgall (Difco).

The results of the enumeration of Lactobacillus spp. were descriptively analyzed. For the antagonism, the nonparametric Kruskal-Wallis test was used to compare the means at $5 \%$ significance (Sampaio, 2002). The profile of antimicrobial susceptibility testing and the sensitivity to bile salts and gastric $\mathrm{pH}$ were qualitatively assessed according to Charteris et al. (1998) and Walker and Gilliland (1993).

\section{RESULTS AND DISCUSSION}

The average results of the enumeration of Lactobacillus spp. are shown in Table 1. The batches 2 and 4 of brand $E$ and 1 and 5 from brand $\mathrm{F}$, which represents $13.3 \%$ of the samples that showed counts inferior to $1.0 \times 10^{6} \mathrm{CFU} / \mathrm{mL}$, which are lower than the values established by the Brazilian legislation (Brasil, 2007).

Table 1. Enumeration of Lactobacillus spp. (CFU/mL) in 30 samples of six brands of fermented milks commercialized in Belo Horizonte, Brazil

\begin{tabular}{|c|c|c|c|c|c|c|}
\hline \multirow{2}{*}{$\begin{array}{l}\text { Product - } \\
\text { Sample* }\end{array}$} & \multicolumn{5}{|c|}{ Batches } & \multirow{2}{*}{$\begin{array}{c}\text { Mean } \\
(\mathrm{CFU} / \mathrm{mL})\end{array}$} \\
\hline & 1 & 2 & 3 & 4 & 5 & \\
\hline A - L. casei & $7.2 \times 10^{8}$ & $5.4 \times 10^{8}$ & $1.1 \times 10^{9}$ & $1.4 \times 10^{8}$ & $3.2 \times 10^{8}$ & $5.6 \times 10^{8}$ \\
\hline B - L. casei & $1.7 \times 10^{8}$ & $2.0 \times 10^{7}$ & $5.0 \times 10^{6}$ & $1.8 \times 10^{8}$ & $2.1 \times 10^{8}$ & $1.2 \times 10^{8}$ \\
\hline C - L. casei & $2.4 \times 10^{8}$ & $4.3 \times 10^{8}$ & $6.0 \times 10^{6}$ & $1.2 \times 10^{9}$ & $1.9 \times 10^{8}$ & $4.1 \times 10^{8}$ \\
\hline D - L.casei & $5.7 \times 10^{8}$ & $6.0 \times 10^{8}$ & $4.1 \times 10^{8}$ & $3.5 \times 10^{8}$ & $9.8 \times 10^{8}$ & $5.8 \times 10^{8}$ \\
\hline E - L. acidophilus & $4.3 \times 10^{6}$ & $9.0 \times 10^{5}$ & $1.6 \times 10^{6}$ & $3.6 \times 10^{5}$ & $3.0 \times 10^{6}$ & $2.0 \times 10^{6}$ \\
\hline $\mathrm{F}-$ L. jonhsoni & $<1.0 \times 10^{3}$ & $6.9 \times 10^{6}$ & $2.2 \times 10^{6}$ & $1.5 \times 10^{6}$ & $9.5 \times 10^{5}$ & $<2.3 \times 10^{6}$ \\
\hline
\end{tabular}

* Species of Lactobacillus according to the product label 
All batches of brands $\mathrm{E}$ and $\mathrm{F}$, lots 2 and 3 of brand B and brand C batch $3(43.3 \%$ of total samples analyzed) were non-compliant in accordance with the standards established by the Brazilian legislation (Brasil, 2008), since they were not viable Lactobacillus spp. Therefore, such products would not be able to satisfactorily promote beneficial effects to the host.

The products brands $\mathrm{E}$ and $\mathrm{F}$ presented lower mean counts of Lactobacillus spp., compared with the mean results of the other products which averaged values higher than $10^{8} \mathrm{CFU} / \mathrm{mL}$. The concentration of microorganisms in the product to be consumed must to be approximately one to two logarithms above the desired concentration in the small intestine $\left(10^{7} \mathrm{CFU} / \mathrm{g}\right.$ of fecal content), since 1-2 $\log$ of bacteria may be inactivated in the digestive tract.

The observed variation in the enumeration of Lactobacillus spp. between batches of products, mainly $\mathrm{C}$ and $\mathrm{F}$, may be associated with failures in monitoring critical control points during the manufacturing process, transport and storage of the product. Even under refrigeration, the lactic acid bacteria produce lactic acid during storage, a phenomenon known as post-acidification, directly affecting the viability of these bacteria (Naidu et al., 1999).

The results of antagonism test by Lactobacillus spp. against indicator microorganisms are shown in Table 2. The microorganisms isolated from fermented milks showed antagonistic activity against all pathogens.

Lactobacillus spp. of the brands A and B inhibited all pathogenic microorganisms and inhibited smaller number of desirable bacteria. Relying solely on these results, samples A and B of the products best meet the call to be probiotic. These samples also showed similar $(\mathrm{P}>0.05)$ mean values of inhibition haloes (Table 3) for samples of the products C, D and E both indicators against pathogenic microorganisms, and against Lactobacillus spp.

Table 2. Mean results (diameters of inhibition haloes in $\mathrm{mm}$ ) of in vitro antagonism test of Lactobacillus spp. isolated from fermented milks $(n=30)$ against indicators microorganisms

\begin{tabular}{lcccccc}
\hline Product - & \multicolumn{7}{c}{ Revealing microorganisms } \\
\cline { 2 - 7 } Sample* & 1 & 2 & 3 & 4 & 5 & 6 \\
\hline A - L. casei & 11.51 & 0.00 & 0.00 & 51.00 & 40.01 & 25.87 \\
B - L. casei & 7.54 & 0.00 & 0.00 & 67.01 & 38.38 & 40.07 \\
C - L. casei & 3.49 & 5.47 & 4.03 & 58.96 & 36.05 & 37.26 \\
D - L. casei & 18.74 & 10.86 & 0.00 & 62.75 & 44.85 & 37.76 \\
E - L. acidophilus & 14.68 & 11.74 & 4.74 & 74.64 & 48.09 & 42.17 \\
\hline
\end{tabular}

Legend: $1=$ L. casei, $2=$ L. acidophilus, $3=$ L. acidophilus $\mathrm{ICB}, 4=S$. Typhimurium ATCC $13076,5=$ S. aureus ATCC 29313, and $6=E$. coli ATCC 25922. * Lactobacillus species according to the label.

Table 3. Means of the diameters of inhibition haloes ( $\mathrm{mm}$ ) displayed by Lactobacillus spp. isolated from fermented milks against pathogenic microorganisms and other Lactobacillus spp.

\begin{tabular}{lcccc}
$\begin{array}{l}\text { Product - } \\
\text { Sample* }\end{array}$ & $\begin{array}{c}\text { Inhibition halo } \\
(\mathrm{mm}) \text { Pathogens }\end{array}$ & $\begin{array}{c}\text { Coefficient of } \\
\text { variation (\%) }\end{array}$ & $\begin{array}{c}\text { Inhibition halo } \\
(\mathrm{mm}) \\
\text { Lactobacillus }\end{array}$ & $\begin{array}{c}\text { Variation } \\
\text { coeficient }(\%)\end{array}$ \\
\hline A - L. casei & $38.96 \mathrm{a}$ & 35.80 & $3.83 \mathrm{~b}$ & 206.58 \\
B - L. casei & $48.48 \mathrm{a}$ & 37.87 & $2.51 \mathrm{~b}$ & 300.40 \\
C - L. casei & $44.09 \mathrm{a}$ & 32.57 & $4.32 \mathrm{~b}$ & 154.40 \\
D - L. casei & $48.45 \mathrm{a}$ & 34.18 & $9.86 \mathrm{~b}$ & 100.71 \\
E - L. acidophilus & $54.96 \mathrm{a}$ & 30.07 & $10.38 \mathrm{~b}$ & 97.69 \\
\hline
\end{tabular}

Means followed by distinct letters in the same line are different $(\mathrm{P}<0.05) .{ }^{*}$ Lactobacillus species according to the label.

There was no difference $(\mathrm{P}>0.05)$ when comparing the antagonistic activity of Lactobacillus spp. isolated from fermented milks against the other Lactobacillus spp. or pathogenic microorganisms. However, the means against pathogenic microorganisms were higher $(\mathrm{P}<0.05)$ than the means against other Lactobacillus spp., a desirable outcome 
considering the use of these microorganisms as probiotics.

The antagonistic activity of Lactobacillus spp. against undesirable microorganisms was described by Guedes Neto et al. (2005), which tested the in vitro antagonist action of lactic acid bacteria isolated from coalho cheese against indicator microorganisms and observed that all the Lactobacillus spp. were able to inhibit the strains of Staphylococcus spp. and E. coli. Other authors also observed antagonistic activities of Lactobacillus spp. against undesirable microorganisms like E. coli, S. aureus and Salmonella spp. (Chaves et al., 1999, Chioda et al., 2007; Pereira and Gómez, 2007; Barros et al., 2009; Pribul et al., 2011).
The results demonstrate the antagonist activity of an important technological perspective for the use of these Lactobacillus spp. in food preservation, controlling the pathogens and providing beneficial effects to human health. The results of in vitro susceptibility profile of Lactobacillus spp. to the antimicrobials are shown in Table 4. All strains of Lactobacillus spp. were resistant to four antimicrobials (ciprofloxacin, ceftazidime, oxacillin and vancomycin) and showed sensitivity to three (erythromycin, clindamycin and tetracycline). Compared to other antimicrobials (gentamicin, streptomycin and penicillin), the samples showed different susceptibility profiles.

Table 4. Profile of susceptibility to the antimicrobial Lactobacillus spp. isolated from fermented milk

\begin{tabular}{lcccccc}
\hline \multirow{2}{*}{ Antimicrobial } & \multicolumn{7}{c}{ Product* } & $\mathrm{C}$ & $\mathrm{D}$ & $\mathrm{E}$ & $\mathrm{F}$ \\
\cline { 2 - 7 } & $\mathrm{A}$ & $\mathrm{B}$ & $\mathrm{S}$ & $\mathrm{S}$ & $\mathrm{R}$ & $\mathrm{S}$ \\
Gentamicin & $\mathrm{S}$ & $\mathrm{S}$ & $\mathrm{S}$ & $\mathrm{S}$ & $\mathrm{S}$ & $\mathrm{S}$ \\
Eritromicin & $\mathrm{S}$ & $\mathrm{S}$ & $\mathrm{S}$ & $\mathrm{S}$ & $\mathrm{S}$ & $\mathrm{S}$ \\
Clindamicin & $\mathrm{S}$ & $\mathrm{S}$ & $\mathrm{R}$ & $\mathrm{R}$ & $\mathrm{R}$ & $\mathrm{R}$ \\
Ciprofloxacin & $\mathrm{R}$ & $\mathrm{R}$ & $\mathrm{R}$ & $\mathrm{R}$ & $\mathrm{R}$ \\
Ceftazidime & $\mathrm{R}$ & $\mathrm{R}$ & $\mathrm{R}$ & $\mathrm{R}$ & $\mathrm{S}$ & $\mathrm{R}$ \\
Estreptomicin & $\mathrm{MS}$ & $\mathrm{S}$ & $\mathrm{R}$ & $\mathrm{R}$ & $\mathrm{MS}$ & $\mathrm{MS}$ \\
Penicilin & $\mathrm{S}$ & $\mathrm{MS}$ & $\mathrm{MS}$ & $\mathrm{MS}$ & $\mathrm{R}$ & $\mathrm{R}$ \\
Oxacilin & $\mathrm{R}$ & $\mathrm{R}$ & $\mathrm{R}$ & $\mathrm{R}$ & $\mathrm{R}$ & $\mathrm{R}$ \\
Vancomicin & $\mathrm{R}$ & $\mathrm{R}$ & $\mathrm{R}$ & $\mathrm{R}$ & $\mathrm{S}$ & $\mathrm{S}$ \\
Tetracyclin & $\mathrm{S}$ & $\mathrm{S}$ & $\mathrm{S}$ & $\mathrm{S}$ & $\mathrm{S}$
\end{tabular}

Legend: $\mathrm{R}=$ resistant, $\mathrm{MS}=$ moderately susceptible, $\mathrm{S}=$ sensitive. ${ }^{*}$ Species of Lactobacillus according to the label: $\mathrm{A}=$ L. casei, $\mathrm{B}=$ L. casei, $\mathrm{C}=\mathrm{L}$. casei, $\mathrm{D}=\mathrm{D}=$ L. casei, $\mathrm{E}=$ L. acidophilus, $\mathrm{F}=$ L. johnsoniii

Some studies have reported large variations in susceptibility in relation to sensitivity of Lactobacillus spp. to antimicrobials (Neumann and Ferreira, 1995; Charteris et al., 1998, Coppola et al., 2005; Ouoba et al., 2008; Belletti et al., 2009). The authors reported multidrug resistance, which was also noted in this study.

The observed resistance of all samples to vancomycin is due to the intrinsic resistance to this antimicrobial (Teuber et al., 1999). This feature can also be associated with ciprofloxacin, ceftazidime and oxacillin, for all samples of Lactobacillus spp. That showed resistance to these antimicrobials. However, according Salminem et al. (1998), potential probiotic bacteria should be selected not only based on the resistance phenotype, but also in the absence of resistance genes avoiding their transference to other bacteria.
However, the present results demonstrate the potential of Lactobacillus spp. in acquire resistance to antimicrobials, which is cause for concern given that genes for antimicrobial resistance can be transferred by conjugation, among other mechanisms, from pathogenic bacteria to probiotic ones. Therefore, it's important that dairy industries select probiotic starter cultures free of resistance genes in order to ensure food safety and maintaining the character of this type of probiotic product.

The results of in vitro susceptibility profile of Lactobacillus spp. to the gastric pH (2.0) and bile salts $(0.3 \%)$ are shown in Tabela 5. All strains of Lactobacillus spp. were considered tolerant to gastric acid present in less than $12 \%$ inhibition at $\mathrm{pH} 2.0$, and were found to be sensitive to bile salts, present in over $80 \%$ inhibition 
Table 5. Sensitivity of Lactobacillus spp. isolated from fermented milks to gastric $\mathrm{pH}$ and bile salts

\begin{tabular}{ccc} 
Sample & $\begin{array}{c}\text { Sensitivity to } \\
\text { gastric } \mathrm{pH}(\%)\end{array}$ & $\begin{array}{c}\text { Sensitivity to } \\
\text { bile salt }(\%)\end{array}$ \\
\hline A & 6.43 & 97.40 \\
B & 8.97 & 88.94 \\
C & 6.67 & 93.75 \\
D & 9.31 & 91.16 \\
E & 11.13 & 97.87 \\
F & 1.25 & 97.59 \\
\hline
\end{tabular}

Legend: species of Lactobacillus according to the product label: $\mathrm{A}=L$. casei, $\mathrm{B}=L$. casei, $\mathrm{C}=$ L. case , $\mathrm{D}=$ L. casei, $\mathrm{E}=$ L. acidophilus, $\mathrm{F}=L$. johnsonii

In similar studies, samples of Lactobacillus spp. were evaluated for their tolerance or not to the gastric $\mathrm{pH}$ and bile salts as a way to measure the potential of these probiotics (Chateau et al., 1994; Neumann and Ferreira, 1995; Corsetti et al., 2008; Urnau et al., 2012). The results of both studies also found a low resistance to $0.3 \%$ bile salts. However, the results of such studies have found high sensitivity of strains to gastric $\mathrm{pH}$, which was not observed in this work.

The ability of lactic acid bacteria withstand acidic $\mathrm{pH}$, such as the stomach of humans $(\mathrm{pH}$ 2.0) and other domestic mammals (between $\mathrm{pH}$ 2.0 and 4.0), is related to the ability of these pumping protons $\mathrm{H}^{+}$directed to the inside of their cells (when using acid $\mathrm{pH}$ ) by the action of the enzyme F0F1-ATPase. Bile salts are important in the elimination of harmful bacteria in the gastrointestinal tract by their detergent action, capable of solubilizing the plasma membrane of pathogens. This action, however, does not affect only the pathogenic bacteria and probiotic microorganisms must therefore be tolerant to these bile salts that may have beneficial effects to the consumer (Gilliland, 1985).

The greater resistance to low $\mathrm{pH}$ found in this study may be due to acid from which the microorganisms were isolated, since fermented milks tend to have high acidity at the end of its production and throughout its shelf life, apart from the fact such microorganisms are lactic acid bacteria. This may also explain the low resistance encountered to bile salts, since these microorganisms are not naturally resistant to them. This implies a need for the presence of high concentrations of probiotic bacteria in fermented milks for their beneficial effects may be manifested in the consumer.

\section{CONCLUSIONS}

It's concluded that the milks fermented by Lactobacillus spp. found in trade in Belo Horizonte, in its entirety, are in accordance with the legal requirements. However, all samples showed some inhibitory activity against pathogenic microorganisms, as well as good resistance to gastric $\mathrm{pH}$ of 2.0. To ensure probiotic effects, Lactobacillus spp. in these fermented milks should be present in higher counts in some brands, has to be resistant to bile salts and they cannot show multiple resistance to antimicrobials.

\section{ACKNOWLEDGEMENTS}

The authors acknowledge the support and thank the Fundação de Amparo à Pesquisa do Estado de Minas Gerais (FAPEMIG).

\section{REFERENCES}

BARROS, M.R.; ANDREATTI FILHO, R.L.; LIMA, E.T.; CROCCI, J.A. Avaliação in vitro da atividade inibitória de Lactobacillus spp., isolados do inglúvio e cecos de aves sobre Salmonella. Arq. Bras. Med. Vet. Zootec., v.61, p.863-868, 2009.

BELLETTI, N.; GATTI, M.; BOTTARI, B. et al. Antibiotic resistance of lactobacilli isolated from two Italian hard cheeses. J. Food Protect., v.72, p.21622169, 2009.

BRASIL, Ministério da Agricultura, Pecuária e Abastecimento (MAPA). Instrução Normativa ${ }^{\circ} 46$ de 23 de outubro de 2007. Regulamento Técnico de Identidade e Qualidade de Leites Fermentados. Diário Oficial da União, Brasília, seção 1, p.5, 24 de outubro de 2007.

BRASIL, Ministério da Saúde. Agência Nacional de Vigilância Sanitária (ANVISA). Alimentos com Alegação de Propriedades Funcionais e ou de Saúde, Novos Alimentos/Ingredientes, Substâncias Bioativas e Probióticos. 2008. Disponível em: http://www.anvisa.gov.br/alimentos/comissoes/ tecno_lista_alega.htm Acessado em: 23 ago. 2012.

CHARTERIS, W.P.; KELLY, P.M.; MORELLI, L.; COLLINS, K. Antibiotic susceptibility of potential probiotic Lactobacillus species. J. Food Protect., v.61, p.1636-1643, 1998. 


\section{Cunha et al.}

CHATEAU, N.; DESCHAMPS, A.M.; HADJ SASSI, A. Heterogeneity of bile salts resistance in the Lactobacillus isolates of a probiotic consortium. Lett. Appl. Microbiol., v.18, p.42-24, 1994.

CHAVES, A.M.; SILVA, J.F.C.; PINHEIRO, A.J.R. et al. Seleção de isolados de Lactobacillus acidophilus usados como probióticos em bezerros. Rev. Bras. Zootec., v.28, p.1093-1101, 1999.

CHIODA, T.P.; SCHOCKEN-ITURRINO, R.P.; GARCIA, G.R. et al. Inibição do crescimento de Escherichia coli isolado de queijo "Minas Frescal" por Lactobacillus acidophilus. Cienc. Rural, v.37, p.583585, 2007.

COPPOLA, R.; SUCCI, M.; TREMONTE, P. et al. Antibiotic susceptibily of Lactobacillus rhamnosus strains isolated from Parmigiano Reggiano cheese. Lait, v.85, p.193-204, 2005.

CORSETTI, A.; CALDINI, G.; MASTRANGELO, M. et al. Raw milk traditional Italian ewe cheeses as a source of Lactobacillus casei strains with acid-bile resistance and antigenotoxic properties. Int. J. Food Microbiol., v.125, p.330-335, 2008.

GILLILAND, S.E. Bacterial Starter Cultures for Food. EUA: CRC Press, Boca Raton, Florida, 1985. $175 \mathrm{p}$.

GUEDES NETO, L.G; SOUZA, M.R.; NUNES, A.C. et al. Atividade antimicrobiana de bactérias ácidolácticas isoladas de queijos de coalho artesanal e industrial frente a microorganismos indicadores. Arq. Bras. Med. Vet. Zootec., v.57, p.245-250, 2005.

GUPTA, V.; GARG, R. Probiotics. Indian J. Medic. Microbiol., v.27, p.202-209, 2009.

JOINT WHO/FAO/OIE, Food and Agricultural Organization/World Health Organization Background document for the Joint WHO/FAO/OIE expert. In: Workshop on non-human antimicrobials usage and antimicrobials resistance scientific assessment. Geneva, Switzerland, 2003. 117p.

MOTA, R.M.; MOREIRA, J.L.S.; SOUZA, M.R. et al. Genetic transformation of novel isolates of chicken Lactobacillus bearing probiotic features for expression of heterologous proteins: a tool to develop live oral vaccines. BMC Biotechnol., v.6, n.2, 2006.

NAIDU, A.S.; BIDLACK, W.R.; CLEMENS, R.A. Probiotic spectra of lactic acid bacteria. Crit. Revi. Food Sci. Nutri., v.38, p.13-126, 1999.

NEUMANN, E.; FERREIRA, C.L.L.F. Lactobacillus acidophilus como adjunto dietético: resistência "in vitro" ao suco gástrico, sais biliares, lisozima e quimioterápicos. Rev. Microbiol., v.26, p.59-65, 1995.
OUOBA, L.I.I.; LEI, V.; JENSEN, L.B. Resistance of potencial probiotic lactic acid bacteria and of Arican and European origin to antimicrobials: Determination and transferability of the resistance genes to other bacteria. Int. J. Food Microbiol., v.121, p.217-224, 2008.

PEREIRA, V.G.; GÓMEZ, R.J.H.C. Atividade antimicrobiana de Lactobacillus acidophilus, contra microrganismos patogênicos veiculados por alimentos. Cienc. Agr., v.28, p.229-240, 2007.

PRIBUL, B.R.; PEREIRA, I.A.; SOARES, L.C. et al. Resistência bacteriana e ação das bacteriocinas de Lactobacillus spp em Staphylococcus aureus isolados de mastite bovina. Arq. Bras. Med. Vet. Zootec., v.63, p.744-748, 2011.

REID, G. Microbiology: categorize probiotics to speed research. Nature, v.485, p.446-446, 2012.

ROBINSON, R.K. Therapeutic properties of fermented milks. New York: Elsevier, 1991. 185p.

SALMINEM, S.; VON WRIGHT, A; MORELLI, L. et al. Demonstration of safety of probiotics - a review. Int. J. Food Microbiol., v.44, p.93-106, 1998.

SAMPAIO, I.B.M. Estatística aplicada à experimentação animal. Belo Horizonte: Fundação de Ensino e Pesquisa em Medicina Veterinária e Zootecnia, 2002. 265p.

TAGG, J.R.; DAJANI, A.S.; WANNAMAKER, L.W. Bacteriocins of Gram-positive bacteria. Bact. Rev., v.40, p.722-756, 1976.

TEUBER, M.; MEILE, L.; SCHWARZ, F. Acquired antibiotic resistence in lactic acid bacteria from food. Ant. van Leeuw. J., v.76, p.115-137, 1999.

URNAU, D.; CIROLINI, A.; TERRA, N.N. et al. Isolamento, identificação e caracterização quanto à resistência ao $\mathrm{pH}$ ácido e presença de sais biliares de cepas probióticas de leites fermentados comerciais. Rev. Inst. Latic. Can. Tost., v.67, p.5-10, 2012.

VANDERZANT C.; SPLITTSTOESSER D.F. Compendium of methods for the microbiological examination of foods. 3.ed. Ame. Public Health Associa., Washington, USA. 1992. 1219p.

WALKER, D.K.; GILLILAND, S.E. Relationships among bile tolerance, bile salt deconjugation, and assimilation of cholesterol by Lactobacillus acidophilus. J. Dairy Sci., v.76, p.956-961, 1993. 